\title{
Die relatiewe belangrikheid van parameters by batevervanging - 'n Sensitiwiteitsanalise
}

\author{
R. Reinecke*, F.O. Schmidt en C. Badenhorst \\ Departement Bedryfsingenieurswese, Universiteit van Stellenbosch, Stellenbosch, 7600, Republiek van Suid-Afrika
}

Ontvang 25 November 1986

\begin{abstract}
This article reports on a study conducted on several important parameters in a real-life problem of asset replacement. A study of the literature revealed the relevant parameters. A spreadsheet programme was created to find an optimum replacement strategy for fork-lift trucks. This same programme was then used for a sensitivity analysis on the most important parameters. The results of this analysis are discussed in this paper. A short user's manual as well as some notes on the working of the program is included.
\end{abstract}

\begin{abstract}
In hierdie artikel word die resultate van 'n ondersoek na die parameters wat besluite ten opsigte van batevervanging beinvloed, bespreek. 'n Literatuurstudie oor hierdie onderwerp het getoon watter parameters in ag geneem moet word. 'n Sigblad-program is ontwikkel met die oog daarop om 'n optimale vervangingstrategie vir vurkhysers te bepaal. Deur middel van dieselfde program is 'n sensitiwiteitsanalise op die belangrikste parameters gedoen. Die resultate van hierdie analise word breedvoerig in die artikel bespreek. 'n Kort bespreking van die program asook 'n gebruikershandleiding word ingesluit.
\end{abstract}

* Aan wie korrespondensie gerig moet word

\section{Inleidlng}

Dit is noodsaaklik dat die top-bestuur van enige maatskappy sekere ekonomiese oorwegings ken en verstaan ten einde die besluite te neem wat die winsgewendheid van die onderneming sal maksimeer. Veral in ondernemings waar daar op groot skaal van masjiene en/of voertuie gebruik gemaak word, is 'n effektiewe strategie met betrekking tot batevervanging een van die heel belangrikste ekonomiese oorwegings.

Met batevervanging word die algehele vervanging van 'n bate bedoel, en nie die opgradering of herstel daarvan nie.

Waarom nie net 'n masjien of voertuig gebruik tot dit onbruikbaar raak, en dan vervang nie?

In sommige ondernemings mag so 'n strategie dalk optimaal wees, maar ons wil graag 'n model ontwikkel wat alle faktore in ag neem, bv. waardevermindering, skrootwaarde, belastingkoers, ensovoorts. Dan raak batevervanging baie meer kompleks - die bepaling van die optimum leeftyd waarop ' $n$ bate vervang moet word. Hierdie beginsel word baie duidelik gëlllustreer in Figuur 1. Indien EJK (ekwivalente jaarlikse koste) teenoor ouderdom ( $n$ ) geplot word, volg die kromme 'n skerp aanvanklike daling na die minimumkoste-punt, wat by die optimale ouderdom is. Daarna toon die totale koste-lyn weer ' $n$ opwaartse neiging as gevolg van toenemende onderhoudskostes en ander uitgawes.

In hierdie ondersoek is 'n program ontwikkel met die oog daarop om 'n optimale vervangingstrategie vir vurkhysers te bepaal (sien bespreking in Eilon, King \& Hutchinson, 1966). Die program kan egter maklik aangepas word vir enige soortgelyke batevervangingsprobleem.

\section{Parameters van belang by batevervanging}

Al die parameters wat in die model gebruik gaan word moet kwantiseerbaar wees - 'n monetère waarde moet daaraan toegeken kan word. Volgens Estes \& JalaliYazdi (1978) is dit beter om 'n batevervangingsanalise op 'n werklikekoste-basis uit te voer eerder as op 'n verwagtekoste-basis (veral wanneer die inflasiekoers beduidend is).

In die praktyk is dit ongelukkig nie altyd moontlik nie. In die studie onder bespreking is gebruik gemaak van historiese data, sê vir die afgelope tien jaar en op grond daarvan is die verwagte kostes vir die volgende tien jaar geskat.

Indien daar aan vurkhysers gedink word, is die mees voor-die-handliggende koste-faktore die aankoopkoste (kapitaaluitgawe), die bedryfskostes (onderhoud, oorhoofs, operateurskoste) en die moontlike herverkoopwaarde daarvan.

In 'n soortgelyke artikel oor die vervanging van vurkhysers gebruik Whyte (1985) bo en behalwe hierdie drie hoofkostes ook faktore soos administratiewe kostes, opleidingskostes, byvoordele van operateurs en buitewerking-koste. Hierdie kostes is egter baie moeilik kwantifiseerbaar. In hierdie opsig stem die skrywer saam

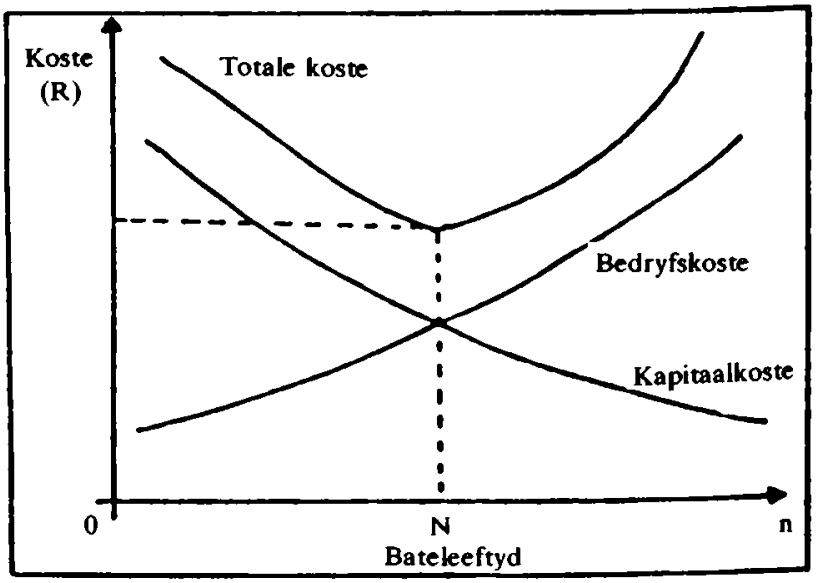

Figuur 1 Die optimumkoste - leeftyd 
met Carson (1964), wat glo dat twyfelagtige oorhoofse kostes gel gnoreer behoort te word.

In hierdie studie, asook in die program, word daar in elke geval na die na-belasting kontantvloei gekyk. Dit is gevolglik net logies dat die koste van kapitaal en die belastingkoers ook ingesluit moet word in die model. Die metode waarteen depresiasie afgeskryf word, asook die depresiasiekoers sal beslis ook kontantvloei beìnvloed. Volledigheidshalwe kan die invloed van sekere toelaes (aanvangs- en belegginsgtoelae) ondersoek word. Aangesien beleggingstoelaes huidiglik uitgefaseer word in die S.A. ekonomie, het die gebruiker van die program egter die opsie om dit te ignoreer.

Carson (1964) se riglyne vir die keuse van faktore by batevervanging verskil vir die aankoop van 'n nuwe soort toerusting teenoor dieselfde soort toerusting. Hy waarsku by die beskouing van ou toerusting dat die oorspronklike koste, geld alreeds spandeer op instandhouding en onrealistiese boekwaardes nie die besluit moet beinvloed nie. Vir nuwe tipes toerusting beklemtoon hy dat besparings wat die nuwe toerusting sal bring wel in ag geneem moet word asook enige veranderings ten opsigte van belastingtoegewings. Besparings wat egter nie duidelik herkenbaar is nie moet liefs buite rekening gelaat word.

In 'n studie waarin hy die vervangingstrategie vir 'n vloot polisiemotors ondersoek het, bespreek Sperling (1978) die baie interessante moontlikheid om die vervangingsperiode in eenhede van afstand te meet en nie in tydseenhede nie. Elke 'periode' of eenheid is hier 'n afstand van 10000 myl.

Smith (1973) het opgemerk dat dit nie noodwendig altyd die beste is om nuwe toerusting aan te koop nie. Hy stel voor dat die volgende vergelyking in gedagte gehou word:

$\underset{\text { leeftyd }}{\text { Optimum }}=\underset{\text { uittree-ouderdom }}{\text { Optimum }}-\underset{\text { aankoopouderdom }}{\text { Optimum }}$

$\mathrm{Na}$ 'n deeglike corweging van al die relevante faktore is besluit om die volgende parameters in te sluit in die model:

Aankoopkoste (kapitaaluitgawe)

Beleggingstoelaag

Aanvangstoelaag

Depresiasiefaktor

Skrootwaarde

Diskontokoers

Belastingkoers

Bedryfskoste.

\section{Loglka en werking van Lotus-123-program}

Aangesien die program redelik gebruikersvriendelik en tot 'n groot mate selfverduidelikend is, sal hier nie ingegaan word op die fynere detail van die werking daarvan nie. Dit is egter noodsaaklik dat sekere opmerkings gemaak word om moontlike verwarring of onsekerheid uit te skakel.

\section{Ekonomiese beginsels}

Vir 'n volledige uiteensetting van die teorie agter die program kan Eilon, et al. (1966) geraadpleeg word. Die skrywers het dit egter in die volgende gevalle noodsaaklik geag om af te wyk van die benadering gevolg in bogenoemde artikel:

- Eilon het die konvensie van totale toekomstige koste as vergelykingsmiddel gebruik. Eenvoudigheidshalwe word hier van die konvensie van gemiddelde jaarlikse koste (in huidige geldwaardes) gebruik gemaak. Hierdie resultaat word oor die projekleeftyd met die faktor (A/P) vermenigvuldig, waaruit ekwivalente jaarlikse kostes (EJK) verkry word.

- Eilon het voorts aangeneem dat jaarlikse uitgawes (bedryfskostes) reeds belastingaanpassings in ag geneem het vóor bewerking deur die program. Die skrywers het egter hulle program so gewysig dat belastingverligting op uitgawes bewerkstellig word. Hierdie berekening word outomaties gedoen.

- By die berekening van kumulatiewe bedryfskoste is daar, in plaas van 'n kontinue integrasie oor die tydsbestek jaar 0 tot $n$, van 'n sommasie oor dieselfde tydperk gebruik gemaak.

- Slegs een depresiasie-stelsel word gebruik, naamlik die fraksie-op-dalende-boekwaarde metode.

\section{Program spesifikasies}

\section{Program raamwerk}

Die program bestaan uit drie dataverwerkers (SEKTOR 1, 2 en 3), en 2 databanke (X1 en X2) om kommunikasie tussen dataverwerkers te bewerkstellig. Data wat in SEKTOR 1 ingevoer is (sien Datatoevoer) word dus via X1 en X2 na SEKTORE 2 en 3 gestuur. Met behulp van grafiese roetines $k a n$ die sensitiwiteit van toegevoerde groothede besigtig word; alle grafieke besigtig word op skyf gestoor met die oog op 'n harde kopie van die grafiek.

\section{Data benodig}

(i) 'n Eenmalige kapitaaluitgawe (opsioneel).

(ii) Bedryfskoste vir elke jaar van bestaan (opsioneel).

(iii) 'n Rentekoers (versuimwaarde $=10 \%$ ).

(iv) 'n Belastingkoers (versuimwaarde $=50 \%$ ).

(v) Beleggingstoelaag (opsioneel).

(vi) Aanvangstoelaag (versuimwaarde $=30 \%$ ).

(vii) Depresiasiefaktor (versuimwaarde $=25 \%$ ).

(viii) Skrootwaardes na elke jaar (opsioneel).

(ix) Parameter van sensitiwiteit (versuimwaarde $=10 \%$ ).

\section{Datatoevoer}

Data kan ingetik word in gespesifiseerde velde. Data kan of vanaf 'n vorige lopie (op skyf) toegevoer word, of volgens 'n vasgestelde deterministiese formule bereken word.

\section{Berekening}

(i) Dataverwerking vind plaas as die F9 sleutel gedruk 
word.

(ii) In SEKTOR 1 as die Rente Grafiek geroep word.

(iii) In SEKTOR 2 en SEKTOR 3 as dit gelaai word.

\section{Data-afvoer}

Alle afvoer is grafies van aand. Grafieke word op die skerm besigtig en dan op skyf gestoor. Nuwe data word in databanke gestoor na afloop van SEKTOR 1.

\section{Gebruik van program}

Plaas Lotus-skyf in aandrywer A en programskyf in aandrywer B. Druk die nodige sleutels om 'n skonn Lotus-sigblad te verkry. Tik nou die volgende in: /fr[CR]. Die program sal nou vanaf skyf gelaai word.

\section{Terminering van program}

Programterminering mag slegs vanuit SEKTORE 2 en 3 gedoen word met behulp van die aangeduide beheerstellings.

\section{Sensitiwiteltsanalise}

Die program maak voorsiening vir 'n sensitiwiteitsparameter (A) met 'n versuimwaarde van $10 \%$ (die gebruiker kan hierdie waarde self kies). Die afvoer van die program word in elke geval in grafiekvorm getoon.

Uit die grafiese voorstelling van Huidige Jaarlikse Rand-Koste vs Jaartal, wanneer sekere ekonomiese parameters gewissel word, kan verskille ten opsigte van optimale leeftyd sowel as relatiewe verskille in gelduitgawes duidelik waargeneem word. Aan die hand hiervan kan afleidings gemaak word oor watter parame. ters die grootste invloed sou hè. Slegs een faktor word op 'n slag gewissel en die ander konstant gehou. Die kurwe vir insetwaarde word op elke grafiek geplot, en weerskante daarvan die $+/-A \%$-en $+/-2 A \%$. afwyking.

\section{Parameter 1: Kapitaaluitgawe}

Alhoewel die kapitaaluitgawe 'n eenmalige uitgawe is, is dit gewoonlik baie groot vergeleke met die ander kosteparameters sodat die invloed daarvan op die EJK beduidend is.

Wisselinge in hierdie parameter het nie 'n groot uitwer king op die optimale leeftyd nie en hierdie leeftyd blyk ongeveer 14 jaar te wees. 'n $10 \%$-variasie in kapitaaluitgawe sal 'n wisseling van ongeveer 5,2\% van die EJK teweegbring (by optimum leeftyd). Hierdie persentasie raak al hoe kleiner by verlenging van die optimum leeftyd (sien Figuur 3).

\section{Rentekoers (koste van kapitaal)}

Die koste van kapitaal oefen 'n redelike sterk invloed uit op die EJK omdat dit so direk in die berekening van kontantvloeie gebruik word. Vir 'n 10\%-verandering in die rentekoers sal die EJK 'n wisseling van ongeveer 2,9\% toon. Hierdie invloed word kleiner by langer leeftye. Variasie in hierdie parameter bei nvloed egter nie eintlik die optimale leeftyd (ongeveer 15 jaar) nie. (sien Figuur 4).

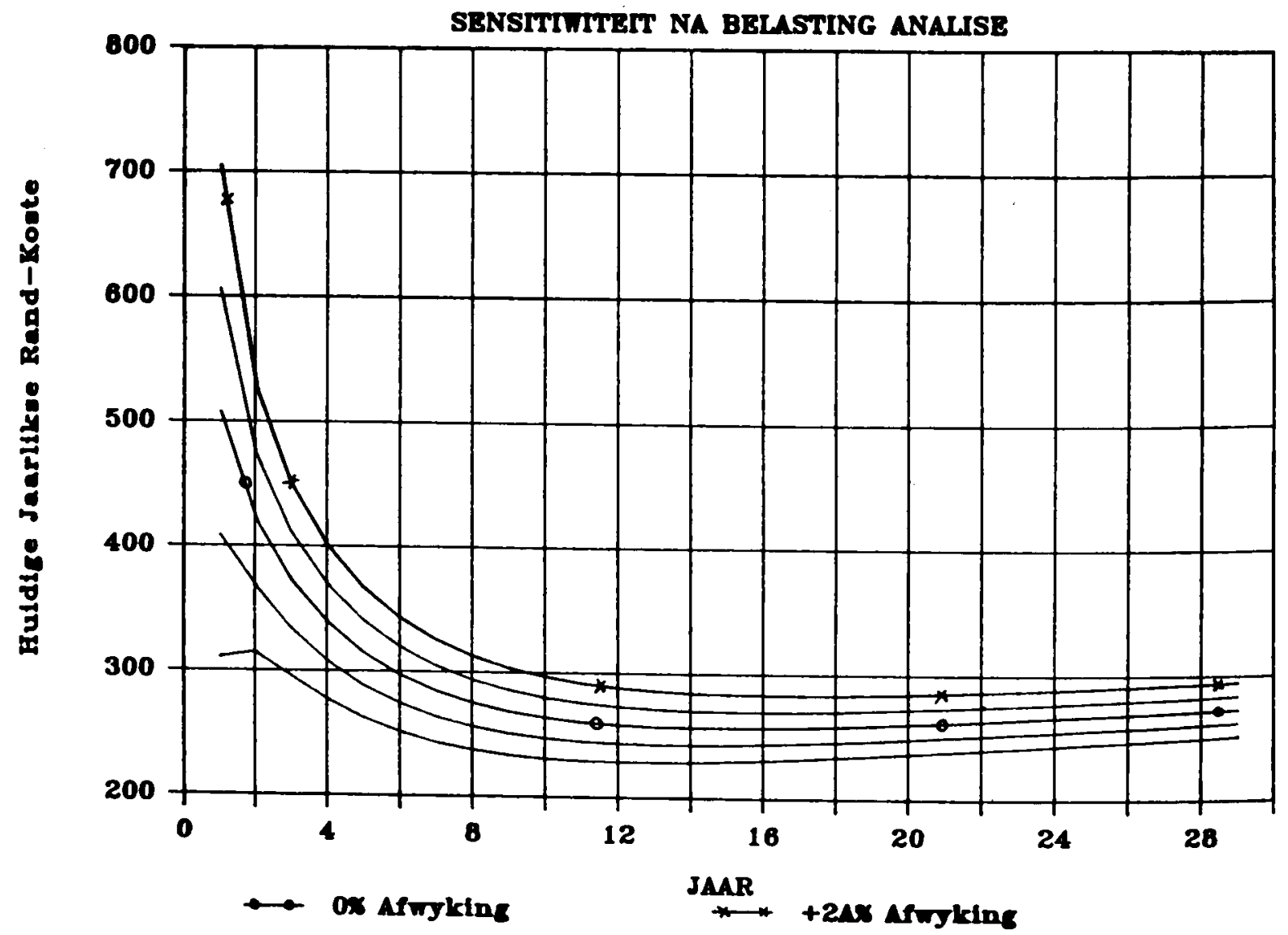

Figuur 3 Variasic in kapitaahuitgawe 


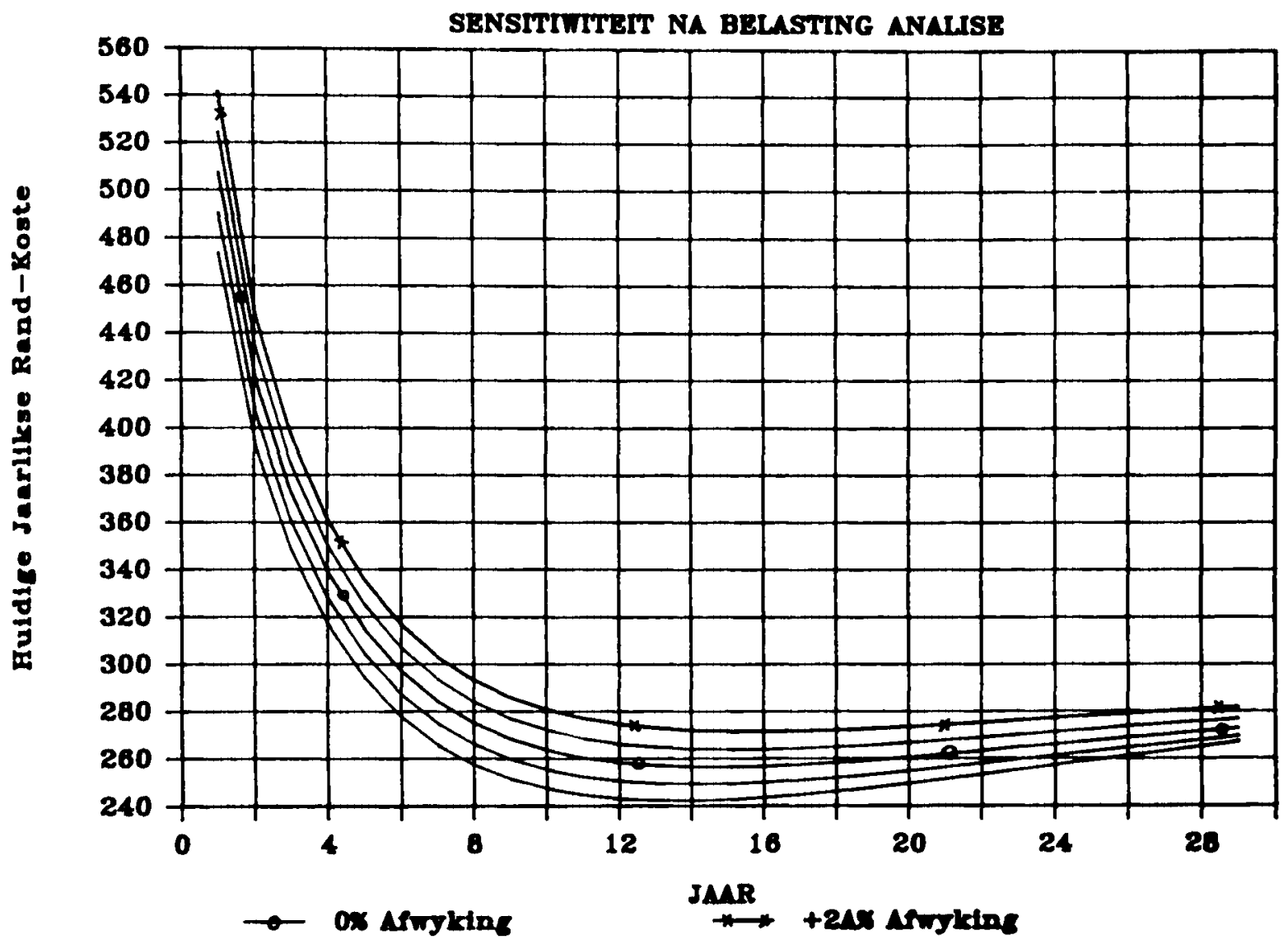

Figuur 4 Variasie in rentekoers

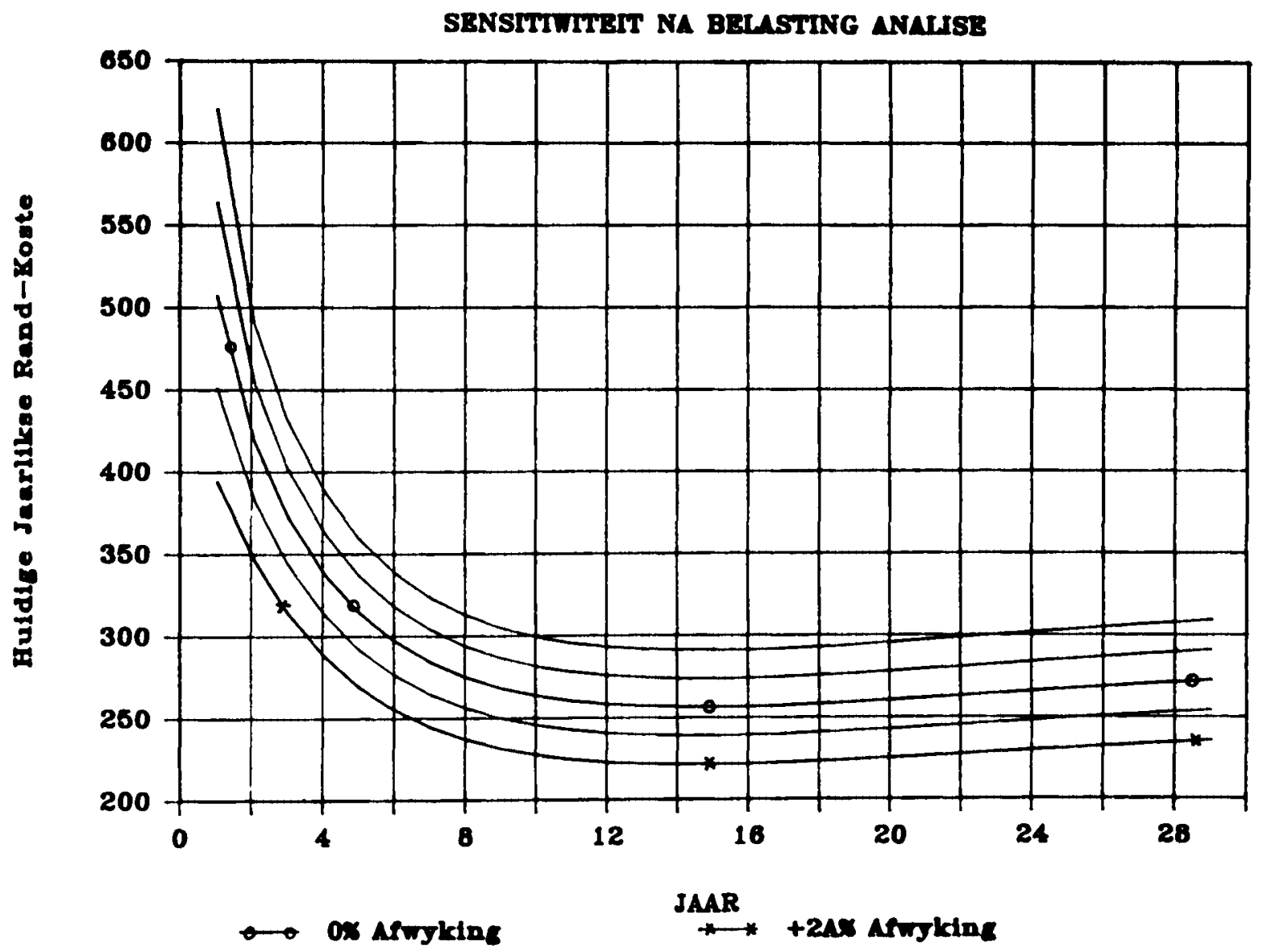

Figuur 5 Variasie in belastingkoers 


\section{Belastingkoers}

Uit die sensitiwiteitsanalise het dit duidelik geblyk dat belastingkoers die parameter met die grootste invloed op die ekwivalente jaarlikse koste is. Die leser mag aanvanklik ietwat verbaas wees hieroor. As dit egter in gedagte gehou word dat belastingkoers direk in berekening gebring word by die bepaling van kontantvloeie, word dit makliker begryp. Belastingkoers beinvloed op sy beurt ander parameters in die kontanvloei-analise, soos aanvangstoelaes, jaarlikse bedryfskostes en waardevermindering.

Dit is verder interessant om daarop te let dat hierdie die enigste parameter onder beskouing is waarvan die invloed nie afhang van die ouderdom van die bate nie. ' $n$ Styging van $10 \%$ in die belastingkoers veroorsaak 'n daling van ongeveer $6,8 \%$ in die EJK, onafhanklik van die leeftyd in jare. (sien Figuur 5). Die optimale leeftyd word feitlik nie beïnvloed deur ' $n$ verandering in belastingkoers nie en is ongeveer 15 jaar.

\section{Jaarlikse uitgawe (bedryfskoste)}

Die grafiese voorstelling hiervan toon 'n baie interessante verloop. 'n $10 \%$-variasie in hierdie parameter toon by Jaar 4 slegs 'n 1,8\%-verandering in EJK, wat skerp toeneem tot $5,9 \%$ in jaar 29 . Hierdie verskynsel word verklaar deur die feit dat jaarlikse kostes wat elke jaar toeneem (a.g.v. inflasie) 'n kumulatiewe invloed op die kontantvloeidiagram het (sien Figuur 6).
Uit die grafiek blyk dit vir groter waardes van die parameter bedryfskoste dat optimale leeftyd afneem van 15 jaar na ongeveer 13 jaar (vir ' $n+20 \%$-verandering). Die teenoorgestelde is ook waar vir 'n verlaging in be dryfskoste.

\section{Skrootwaarde (herverkoopwaarde)}

Die herverkoopwaarde is, soos die aankoopkoste, 'n enkelbedrag. Dit word egter eers aan die einde van 'n bate se leeftyd in berekening gebring. Skommelings in die prys wat vir so 'n bate verkry word, het dus ná Jaar 6 'n weglaatbare invloed op die ekwivalente jaarlikse koste. Die optimale leeftyd word gevolglik ook nie beì nvloed nie (Figuur 7).

\section{Depresiasief aktor}

In Figuur 8 kan gesien word dat ekwivalente jaarlikse koste baie ongevoelig is vir ' $n$ verandering in die depresiasiefaktor. 'n Verhoging van $20 \%$ in die depresiasiekoers sou bv. ' $n$ verlaging van slegs ongeveer $1 \%$ in die EJK tot gevolg hè. Hierdie waarde bly naastenby konstant, ongeag van die ouderdom van die bate. Die optimale leeftyd (+/-15 jaar) bly ook konstant.

\section{Aanvangstoelaag}

Hierdie is ongetwyfeld die parameter waarvoor die kontantvloeisyfers die minste sensitief is. Variasies in hierdie parameter het 'n minimale uitwerking op die EJK asook op die optimum leeftyd (Figuur 9).

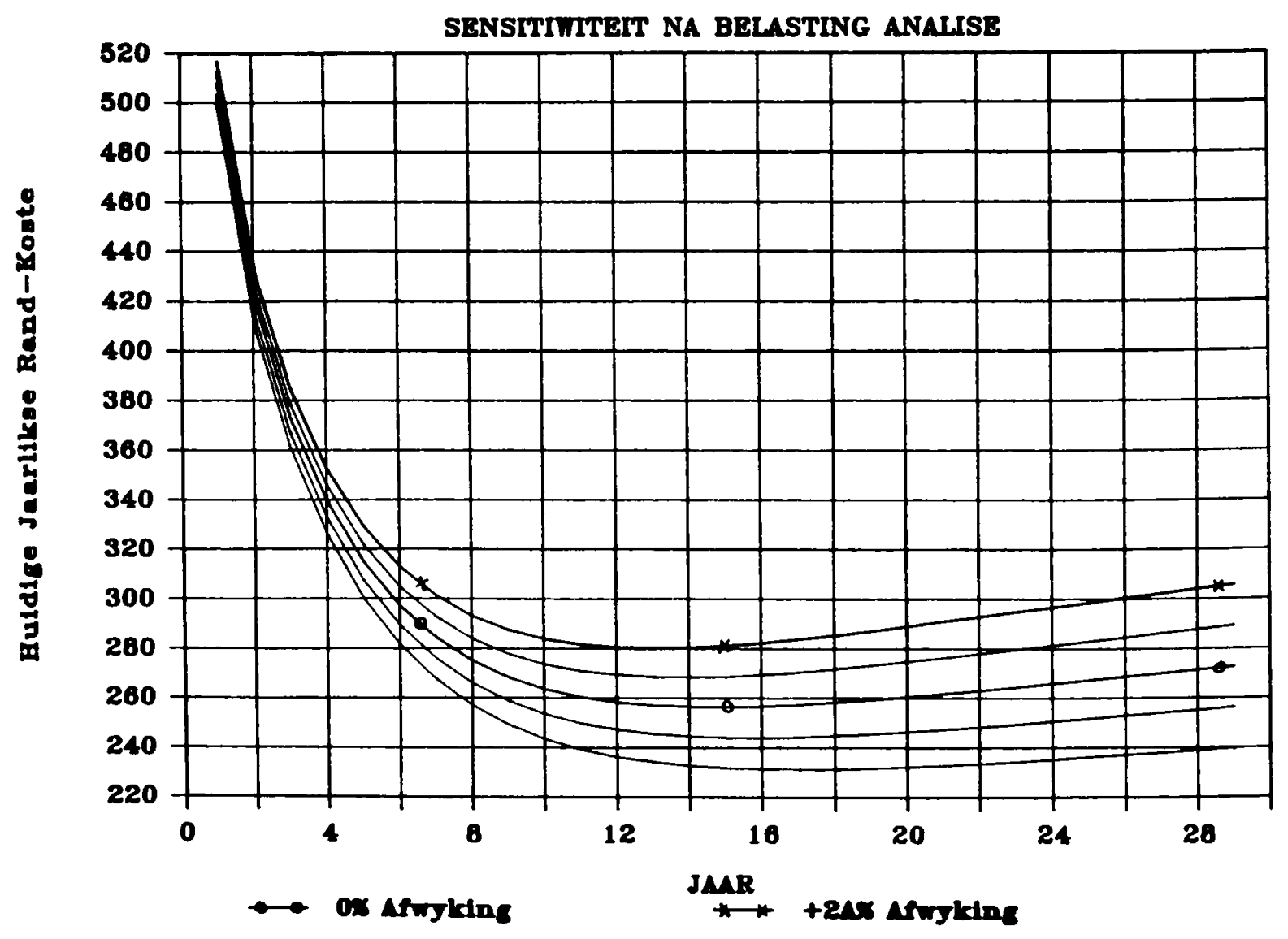

Figuur 6 Variasie in jaarlikse uitgawe 


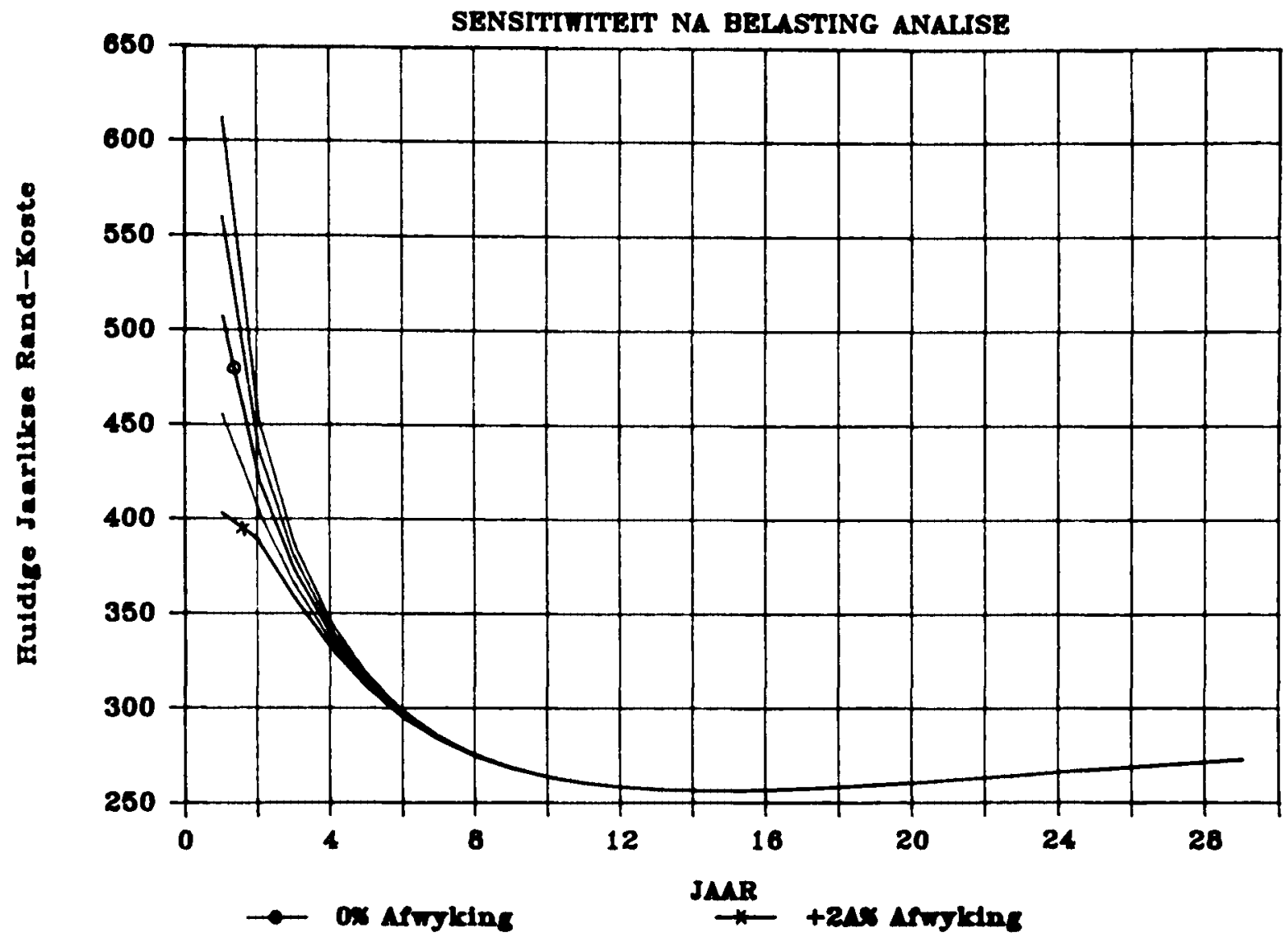

Figuur 7 Variasie in skrootwaarde

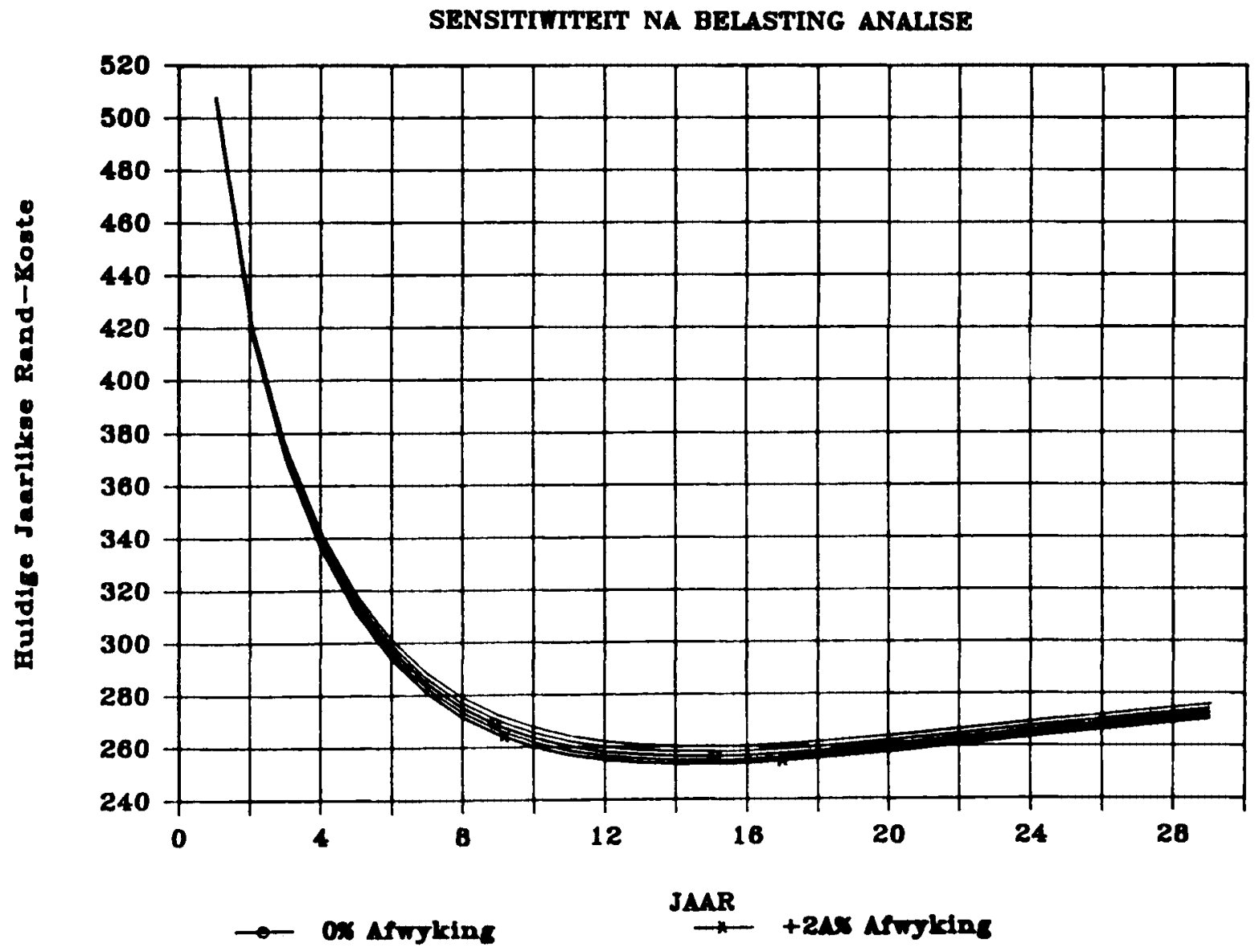




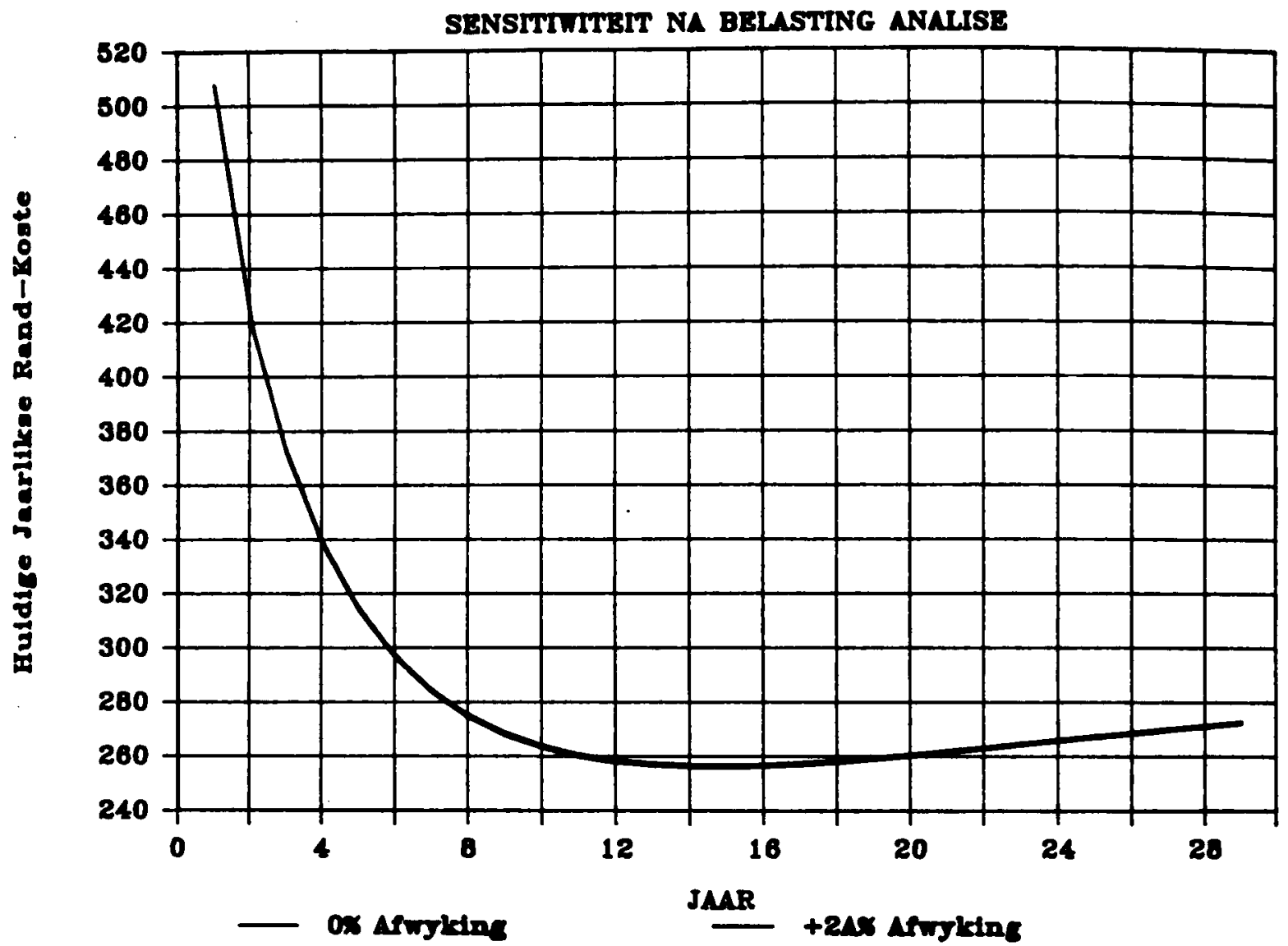

Figuur 9 Variasie in aanvangstoelaag

\section{Bespreking van resultate}

\section{Samevatting}

Die faktore wat die grootste invloed op die finansiele lonendheid van 'n batevervangingsbesluit het, is belastingkoers, kapitaaluitgawe en rentekoers (in hierdie volgorde). Jaarlikse uitgawes (bedryfskoste) beinvloed die kapitaalvloei van bates wat relatief lank gehou word terwyl skrootwaarde 'n veel groter invloed toon in die eerste paar jaar van 'n bate se leeftyd.

Die jaarlikse uitgawe (bedryfskoste) het verreweg die grootste invloed op die optimale leeftyd. Die optimale leeftyd verander egter nie met meer as 4 jaar vir 'n $40 \%$ verandering in bedryfskoste nie. Kapitaaluitgawe is die enigste ander faktor met 'n beduidende invloed op die optimale leeftyd.

\section{Die platkurwe-hipotese}

Indien ekwivalente jaarlikse koste teenoor bateleeftyd geplot word, is die kurwe altyd van die vorm soos in Figuur 2. Dit illustreer ' $n$ verskynsel wat bekend staan as die platkurwe-hipotese ('flat-top hypothesis').

Die praktyk het bewys dat dit dikwels moontlik is om redelik ver van die beste vervangingsleeftyd (deur die model aangedui) af te wyk met 'n relatiewe klein kostetoename. Hierdie hipotese is ook van toepassing op hierdie spesifieke batevervangingsprobleem. Om dus aan te sluit by die sensitiwiteitsanalise kan die volgende twee algemene stellings ondersoek word:

(i) Dit behoort vir hoofbestuurders met baie onder-

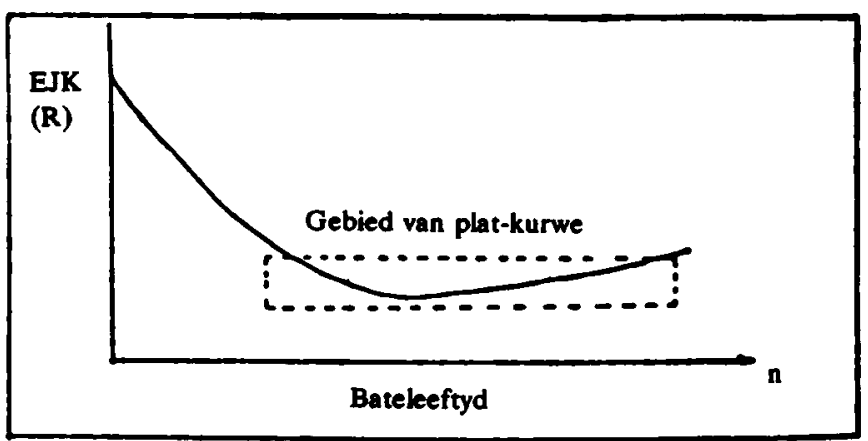

Figuur 2 Ekwivalente jaarlikse koste versus beplanningshorison

vinding moontlik te wees om 'n beleid op 'gevoel' te formuleer wat baie na aan die optimum is.

(ii) As dit so is, sal verdere analise slegs relatief klein verbeteringe teweegbring. Waar groot somme geld op die spel is, mag dit egter noodsaaklik wees.

Slot

'n Bestuurder behoort alle inligting tot sy beskikking te gebruik om enige belangrike besluit te neem, in hierdie geval 'n beleid ten opsigte van batevervanging. ' $n$ Sensitiwiteitsanalise soos die een wat in die artikel beskryf word, is gewoonlik 'n baie handige hulpmiddel in hierdie besluitnemingsproses.

Die rekenaarprogram wat hierdie artikel vergesel is geskep met die doel om 'n instrument in die hand te wees van enige persoon wat ' $n$ belangrike besluit rakende die vervangingsbeleid van 'n bate moet neem. 


\section{Summary}

Most companies have been faced with this problem at one time or another: Should they replace an asset now while it still has a resale value, or should they hang on to it until it breaks down? Every asset has an optimal age, a lifespan where replacement will be most profitable.

All the relevant factors influencing this decision should be carefully selected to ensure a reliable result. In a replacement analysis for fork-lift trucks, the effects of the following parameters were investigated: capital outlay, operating cost, resale value, depreciation factor, cost of capital, taxation rate and investment rebates.

The economic principle of Equivalent Uniform Annual Cost (EUAC) are used in all program calculations.

A sensitivity parameter (default value $10 \%$ ) is used throughout the sensitivity analysis. The sensitivity of every one of the above factors is investigated, while keeping the others constant. The output of the program is in the form of a graph.

From the sensitivity analysis it proved clear that the factors taxation rate, capital outlay and cost of capital (in this sequence) have the largest financial implications for any decisions regarding replacement of assets. Annual operating cost had the largest influence on the optimal life of an asset. On the whole, however, optimal life proves insensitive to the above factors.

The sensitivity analysis described in the article should assist any manager in making major replacement decisions.

\section{Verwysings}

Eilon, S., King, J.R. \& Hutchinson, 1966. A Study in Equipment Replacement, Operat. Res. Quart., vol XVII No. 1, March.

Estes, C.B. \& Jalali-Yazdi, A. 1978. Now Replace Equipment on Actual Cost Basis, Industr. Engin., November.

Whyte, P.C. 1985. Reduce High Cost of Aging Lift Trucks, Industr. Engin.

Carson, G.B. 1964. Production Handbook, Second Edition, New York: The Ronald Press Company.

Sperling, B. 1978. Replacement Analysis in your pocket, Industr. Engin., October.

Smith, O.W. 1973. Engineering Economy: Analysis of Capital Expenditures, Second Edition, Iowa, U.S.A.: The Iowa State University Press. 